\title{
APPLICATION OF MATHEMATICAL MODELLING FOR OPTIMIZATION OF LAND-USE MANAGEMENT
}

\author{
Ruslana Taratula \\ Lviv National Agrarian University, Dubliany, Ukraine \\ e-mail: ruslana.78@ukr.net \\ Oleksandra Kovalyshyn \\ Lviv National Agrarian University, Dubliany, Ukraine \\ e-mail:kovalyshynlesya@ukr.net \\ Zoriana Ryzhok \\ Lviv National Agrarian University, Dubliany, Ukraine \\ e-mail: zoryana.rizhock@gmail.com

\section{Svitlana Malakhova} \\ Lviv National Agrarian University, Dubliany, Ukraine \\ e-mail: sveta_malaxova@ukr.net
}

\begin{abstract}
The work has approved the methods of partial economic evaluation of lands by the indicators of yield capacity of agricultural crops, payback of expenditures and differential income for a typical agricultural enterprise, located on the territory of the natural-agricultural province of the Western Forest-steppe. The research supplies proposals concerning improvement of the methods of economic evaluation of lands in Ukraine on the example of the indicators of economic evaluation of the land use at the farming enterprise "GREEN GARDEN". The indicators are used for the growing of agricultural crops, planning their yield capacity, comparison of the economic fertility of soils and determination of the economic results of growing agricultural crops under the current production conditions in a defined working area.

The research proposes the optimization of land-use management, applying a metrical game on the basis of indicators of the economic evaluation of lands to define the optimal share of agricultural crops in crop rotation. This method can be used to optimize land use in any region. Application of mathematical modeling by indicators of differential income ensures that maximum gross income is obtained under the mixed strategy of the game on better and worse soils in the enterprise.
\end{abstract}

Key words: problems of efficient land use, economic evaluation of land, yield capacity of agricultural crops, payback of expenditures, differential income, modeling.

JEL Classification: $C 130$.

Citation: Taratula R., Kovalyshyn O., Ryzhok Z., Malakhova S., 2019, Application of Mathematical Modeling for Optimization of Land-Use Management, Real Estate Management and Valuation, vol. 27, no. 3, pp. 59-68.

DOI: $10.2478 /$ remav-2019-0025 


\section{Introduction}

In Ukraine, there is a growing need for the application of data which characterize the topography of the location, soil quality, suitability of the land for cultivation and gives a comparative evaluation of the land quality according to the materials of economic evaluation of lands, for the analysis of economic activity by the level of the efficiency of growing some agricultural crops. In order to properly carry out crop rotation on a land property or land use, it is necessary to know the content of the land, as well as use the data of a partial economic evaluation of land so as to estimate the suitability of the land for growing different agricultural crops by means of mathematical modeling.

Land-use models demonstrate the relationship between various driving forces of land-use transformation and are increasingly employed in the forecasting of possible future land uses (USTAOGLU et al. 2016).

Economic land evaluation is a method for predicting of the microeconomic value, obtained from the implementation of a definite system of land use on a definite land area. That forecast is more useful than a purely physical evaluation of land use, since many land use decisions are made on the basis of economic evaluation (Rossiter D., 1995). Methodological approaches to the economic evaluation of land with the application of mathematical modeling for the determination of the indicators of sustainable land-use development are disclosed in the works of D.J. Panel and N.A. Glenn (PANnELl, GLEnN 2000), C.S. Smith and G.T. McDonald (SMITH, McDonAlD 1998), S. Kalogirou (KALOGIROU 2002), A.S. Strokov, E.N. Yakubovich and P.V. Krasilnikov (STROKOV, YAKUBOVICH, KRASILNIKOV 2017), and J.T. Corkindale (CORKINDALE 1998).

The analysis of the economic evaluation of lands in foreign countries reveals that there is no common methodology of carrying it out. For instance, in the USA, the basis of economic evaluation of agricultural lands is agro-climatic estimation, with such criteria as: the structure and size of land use, the location of the farm, the degree of intensification, yield capacity of agricultural crops and production expenditures on different soils, established prices for agricultural products, distance from the land parcel to infrastructure objects and places of their implementation. The main principle of economic evaluation is to determine the degree of impact of some soil differences on the amount of income from growing agricultural crops. The most widely spread method of economic evaluation of agricultural land parcels is to estimate lands according to the net income from the sale of agricultural products as the difference between the value of gross products and production cost per unit of area. The highest net income is calculated according to the 100-grade scale and is compared to the one obtained on worse lands. The economic evaluation of lands is determined by the weighted average, which is the basis for land use and land organization in different states (YUSHKOVA 2014).

In Germany, economic evaluation of lands depicts relative fertility according to economic and organizational production factors and the quality of soils of a land parcel on a 100-grade scale (TRUBINA 2014).

In Great Britain, after the evaluation of lands by natural factors, economic evaluation within the determined classes of lands is carried out according to the degree of productivity. The evaluation is based on the indicator of standard net products. Economic evaluation of lands is calculated by the method of capitalization of the costs of net products according to yield capacity of agricultural crops by comparing yields of some crops under different ways of farming (IVASENKO 2008).

Methods of economic evaluation of land according to the indicators of economic efficiency, productivity and profitability of land use for the purpose of land-use optimization, are recommended to be applied not only in Ukraine, but also in the neighboring countries of the EU, particularly for implementation of a common agrarian policy concerning increased productivity of land resource use in agriculture. The methodology of supporting investments and methodic approaches to modeling the efficient use of agricultural lands have been studied in the works of Ukrainian and foreign scientists (TEMPLE et al. 2018; DEATON 2018).

\section{Data and Methods}

The methodological basis of economic land valuation is the doctrine of land as the main means of production in agriculture (ZAMULA 2008). The issue of economic evaluation of land landed on the front burner in the early 60s due to the need to improve agricultural production planning. In 19741975, production works concerning the economic evaluation of land were performed on the territory of Ukraine. In 1976, the Ministry of Agriculture of the USSR approved an "All-union methodology of 
land evaluation (temporary)" (Ministry of ..., 1976). According to the methodology, implementation of land-evaluating works included conducting general and partial economic evaluation of lands with consideration to the efficiency of the main grown agricultural crops. The general economic evaluation of lands was performed according to the indicators of the costs of gross outcome, payback of expenditures and differential income, and the partial - according to yield capacity of crops, cost recovery and differential income (Law of ..., 2001). Today, two basic methods of economic evaluation of land resources exist: rent and cost (TROCHLYUK 2014).

The method of applying economic land evaluation is disclosed on the example of land use in Ukraine. Yield capacity of each definite agricultural crop in each working area is one of the main indicators of scientific-based planning of agricultural production, which is differentiated with consideration of land quality. The yield capacity is measured by the formula:

$$
Y i=\frac{\text { Yave }}{\text { Swa }} \times \text { Stj }
$$

where: $\mathrm{Yi}$ - is the yield capacity of an agricultural crop on a definite working area of land use; Yave is the average yield capacity at the enterprise, hwt/ha; Swa - is the weighted average score of soil bonitet in the land-use management; Stj - is the total score of the bonitet of the $\mathrm{i}$ agrogroup of soils.

Indicators of the expenditure payback period and differential income are measured by the formula:

$$
\begin{gathered}
\text { PEa }=\frac{Y i}{E} \\
\text { DIa }=\mathrm{Yi} \times \mathrm{Pi}-1.35 \times \mathrm{E}
\end{gathered}
$$

where: PEa - is payback of expenditures in the working area, hwt/100 UAH of expenditures; $\mathrm{Yi}$ - is the yield capacity of an agricultural crop in a definite working area of the land-use management, $\mathrm{hwt} / \mathrm{ha}$; $\mathrm{E}$ - total expenditures of growing agricultural crops in the land-use management, UAH / ha; DIa - differential income in the working area, $€ / \mathrm{ha} ; \mathrm{Pi}$ - sale price for agricultural crops, hwt/ UAH.

To calculate the score of a partial economic evaluation of lands in a definite working area, it is necessary to determine their score price according to expenditure and differential income:

$$
\begin{aligned}
& \text { PSpe }=\frac{P E}{S} \\
& \text { PSdi }=\frac{D I}{S}
\end{aligned}
$$

where: PSpe - is a price of the score according to payback of expenditures, hwt/100 UAN; PE - is payback of expenditures in the land-use management, hwt/100 UAH; $\mathrm{S}$ - is the score of bonitet of a crop in a working area; PSdi - is a price of the score according to the differential income; DI - is the differential income in land-use management, UAH / ha.

Score of evaluation of a working area according to the payback of expenditure and differential income:

$$
\begin{aligned}
& \text { SPEa }=\frac{\text { PEa }}{\text { PSpe }} \\
& \text { SDIa }=\frac{\text { DIa }}{\text { PSdi }}
\end{aligned}
$$

where: SPEa - is the score of evaluation of a working area according to the payback of expenditures; SDIa - is the score of the evaluation of a working area according to the differential income; PEa - is payback of the expenditures at a working area, hwt/100 UAH of expenditures; PSpe - is a price of the score according to payback of expenditures; DIa - is the differential income at a working area, $\mathrm{UAH} / \mathrm{ha}$; PSdi - is a price of the score according to the differential income.

The indicators of economic evaluation of lands of the $i$ working area of the land-use management according to the value of gross output (GOi), payback of expenditures (PEi) and differential income (DIi) are measured by the formulas:

$$
\begin{gathered}
\mathrm{GOi}=\mathrm{Ai} \times \mathrm{Yi} \times \mathrm{Pi} \\
\mathrm{PEi}=\frac{\mathrm{GOi}}{\mathrm{E}_{\mathrm{i}}} \\
\mathrm{DIi}=\mathrm{GOi}-1,35 \times \mathrm{E}
\end{gathered}
$$

where: $\mathrm{A}-$ is the area of evaluated agrarian groups of soils of the land-use management, ha. 


\section{S sciendo}

The weighted average score of economic evaluation of lands (Swa) according to its indicators in land-use management is calculated by the formula:

$$
\text { Swa }=\frac{\sum \mathrm{A}_{\mathrm{S}} \mathrm{Si}}{\sum \mathrm{Ai}}
$$

where: $\mathrm{Si}$ - is the score according to the indicator of economic evaluation of lands for an agrogroup of soils of the land-use management (STUPEN, MYKULA, RADOMSKI 2012; MAHAZYNSHCHYKOV 1991).

\section{Empirical results}

Some of the working areas and crop rotation fields of the farming enterprise "GREEN GARDEN" are the object for the determination of land management optimization according to the indicators of the economic evaluation of lands. The territory of the land-use management is located in the village of Novosilky, Busk district, Lviv region, in the moderate continental climatic zone. According to the data of recordings, the enterprise employs 37.8 ha of arable lands. The cadastral number of the enterprise is 4620684000:08:000:0160 (Fig. 1). The farming enterprise is located in a natural-agricultural province of the Western Forest-steppe; this determines specialization of its agricultural production and forms of land-use management, which is typical for the mentioned area.

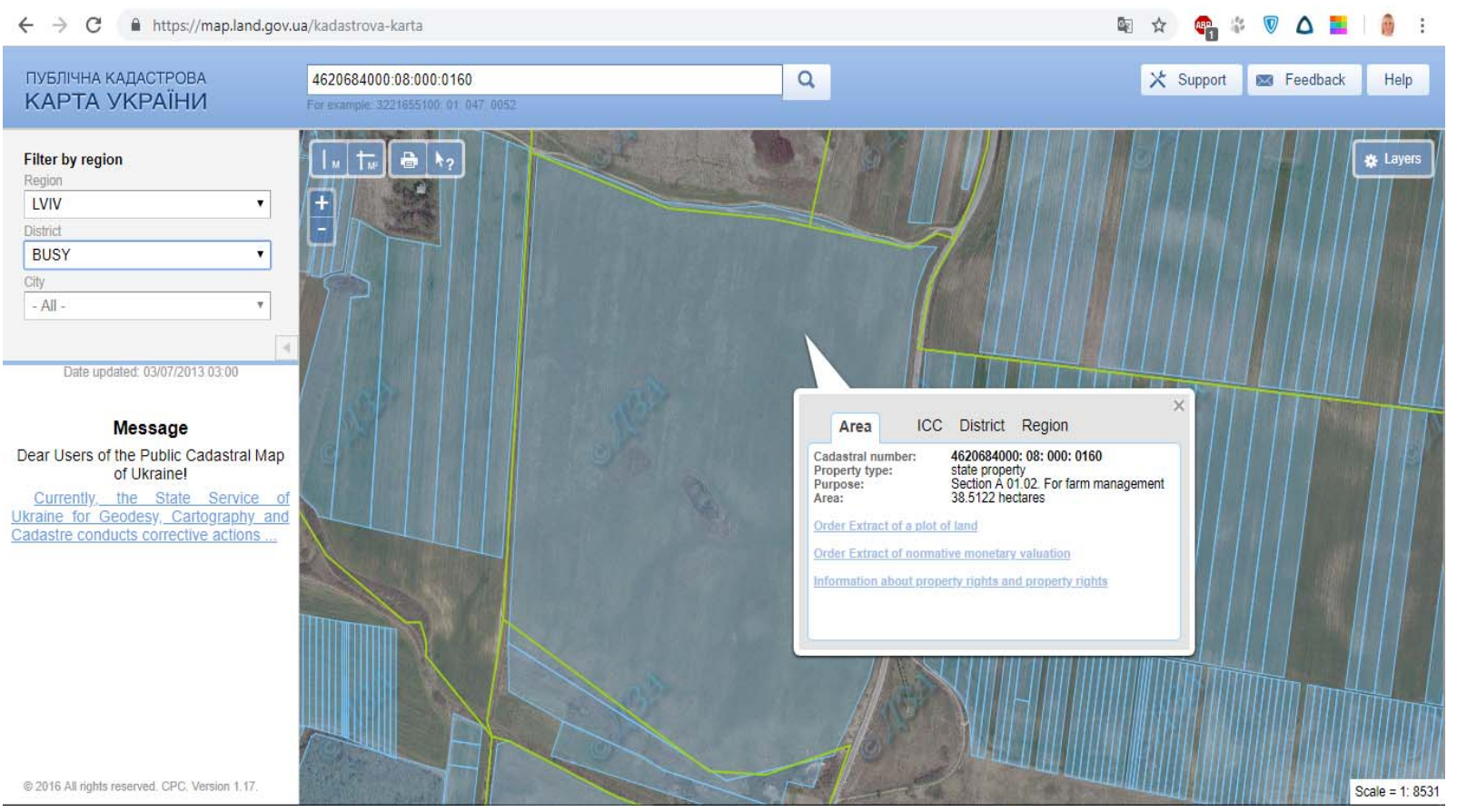

Fig. 1. Location of the farming enterprise "GREEN GARDEN" on a public cadastral map of Ukraine. Source: Public cadastral map of Ukraine.

According to genetic-morphological specifics and data on soil observations (Cherkasy regional ..., 2017) on the studied territory of the enterprise, the following soils were determined:

- $33 \mathrm{~g}$ - gray podzolic light eroded loamy soils on forest rocks (16.5 ha);

- $40 \mathrm{~g}$ - dark-gray podzolic clay medium washed out light loamy soils on forest rocks (21.3 ha).

Each working area of each agro-productive group of soils requires the determination of the indicators of economic evaluation of lands according to their productivity, efficiency of employment and profitability of an area unit (Law of ..., 2001). Materials of the economic evaluation of lands do not correspond to actual data according to the results of agricultural production and do not provide a reliable depiction of the current economic conditions of farming activity (KOVALYSHYN, KRYSHENYK, HAVRYSHKIV 2014; KOVALYSHYN, RYZHOK 2017). The problem of determining differential rent income is complicated by the lack of information on the current values of the required output indicators, in particular through simplification, and often the lack of appropriate accounting and reporting (SMAHA 2016). The reason behind such a result is that the calculations concerning the economic evaluation of lands in 1988 were based on the average data of differential rent income of cereal production to find their weighted average indicator. Consequently, the lack of an objective evaluation of land is one of 
the reasons behind unsatisfactory usage of agricultural lands, and sometimes non-economic treatment of the land.

It is therefore necessary to calculate new indicators of the partial economic evaluation of land in terms of working areas of land-use management. Considering the fact that the farming enterprise is located in the natural-agricultural province of the Western Forest-steppe, within the territory of Borshchovychi natural-agricultural district, Formula 1 is recommended for the calculation of yield capacity according to the Main Statistical Office in the Lviv region (Main Statistical Office of..., 2017) of such agricultural crops in crop rotation as I - winter wheat, II - sugar beets, III - grain maize, IV barley, V - winter rye (Table 1) (ZUBETS, SYTNYK, BEZUHLYI 2008).

Table 1

Calculation of yield capacity of agricultural crops at the enterprise, 2017

\begin{tabular}{|c|c|c|c|c|c|c|c|c|c|c|}
\hline & \multicolumn{10}{|c|}{ Agricultural crops } \\
\hline & \multicolumn{2}{|c|}{ Winter wheat } & \multicolumn{2}{|c|}{ Sugar beets } & \multicolumn{2}{|c|}{ Grain maize } & \multicolumn{2}{|c|}{ Barley } & \multicolumn{2}{|c|}{ Winter rye } \\
\hline & 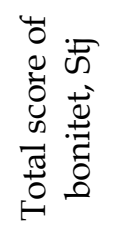 & 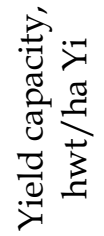 & 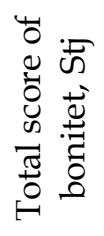 & 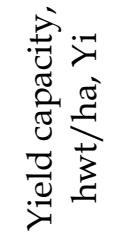 & 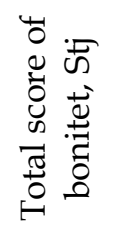 & 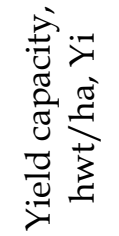 & 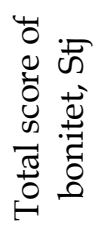 & 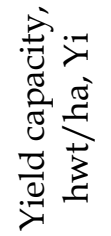 & 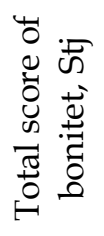 & 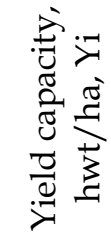 \\
\hline \multirow{2}{*}{$\begin{array}{ll}\text { Code of a } & 33 \\
\text { soil } & \\
\text { agrogroup } & 40\end{array}$} & 38 & 43.74 & 42 & 257.36 & 37 & 57.57 & 37 & 43.56 & 38 & 23.39 \\
\hline & 51 & 58.71 & 52 & 318.64 & 47 & 73.12 & 50 & 58.86 & 51 & 31.39 \\
\hline $\begin{array}{l}\text { Weighted } \\
\text { average score of } \\
\text { bonitet at the } \\
\text { enterprise, Swa }\end{array}$ & \multicolumn{2}{|c|}{45} & \multicolumn{2}{|c|}{47} & \multicolumn{2}{|c|}{43} & \multicolumn{2}{|c|}{43} & \multicolumn{2}{|c|}{45} \\
\hline $\begin{array}{l}\text { Average yield } \\
\text { capacity at the } \\
\text { enterprise, } \\
\text { hwt/ha Yave }\end{array}$ & \multicolumn{2}{|c|}{51.8} & \multicolumn{2}{|c|}{288.0} & \multicolumn{2}{|c|}{66.9} & \multicolumn{2}{|c|}{51.8} & \multicolumn{2}{|c|}{27.7} \\
\hline
\end{tabular}

Source: own study.

To calculate the indicators of the partial economic evaluation of land according to the payback of expenditures and differential income, the authors of the article used "The report about the main economic indicators of agricultural enterprise performance in the Lviv region in 2017" (Main department ..., 2017). It supplied the value of expenditures connected with growing agricultural crops and the sale price according to the data of online grain stock market of Ukraine "Grain Trade" (Table 2) (E-exchange of ..., 2017).

Having determined the total expenditures and sale price while growing agricultural crops under the indicators of their average yield capacity in a working area of the enterprise, the researchers calculate the indicators of the payback of expenditures and differential income (Table 3) using Formulas 2 and 3. The calculations are presented in the European currency in conversion to $1 €^{*}=30.5$ UAH.

Table 2

Expenditures and sale price of growing crops, 2017

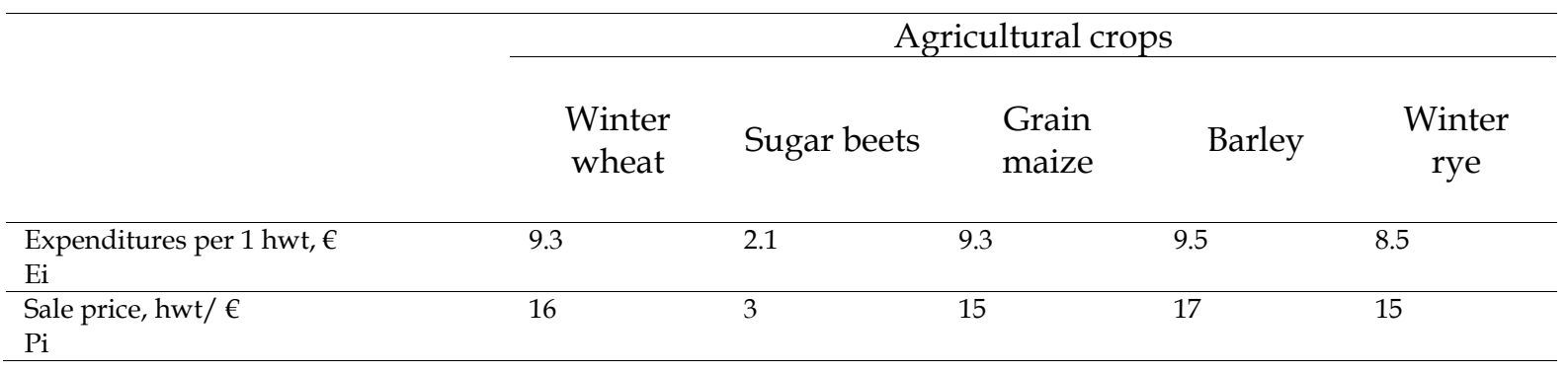

Source: own study. 
Table 3

Calculation of the indicators of the partial economic evaluation of lands according to the payback of expenditures and differential income in a working area of the enterprise, 2017

\begin{tabular}{|c|c|c|c|c|c|c|c|c|c|c|}
\hline & \multicolumn{10}{|c|}{ Agricultural crops } \\
\hline & \multicolumn{2}{|c|}{ Winter wheat } & \multicolumn{2}{|c|}{ Sugar beets } & \multicolumn{2}{|c|}{ Grain maize } & \multicolumn{2}{|c|}{ Barley } & \multicolumn{2}{|c|}{ Winter rye } \\
\hline & $33 \mathrm{~g}$ & $40 \mathrm{~g}$ & $33 \mathrm{~g}$ & $40 \mathrm{~g}$ & $33 \mathrm{~g}$ & $40 \mathrm{~g}$ & $33 \mathrm{~g}$ & $40 \mathrm{~g}$ & $33 \mathrm{~g}$ & $40 \mathrm{~g}$ \\
\hline $\begin{array}{l}\text { Yield capacity, } \\
\text { hwt/ha } \\
\text { Yi }\end{array}$ & 43.74 & 58.71 & 257.36 & 318.64 & 57.57 & 73.12 & 43.56 & 58.86 & 23.39 & 31.39 \\
\hline $\begin{array}{l}\text { Total } \\
\text { expenditures, } € \\
\text { /ha } \\
\text { E }\end{array}$ & & & & & & & $4 \mathrm{c}$ & & & \\
\hline $\begin{array}{l}\text { Payback of } \\
\text { expenditures, } \\
\text { hwt/100 } € \\
\text { PEa }\end{array}$ & 0.30 & 0.40 & 1.39 & 1.72 & 0.30 & 0.39 & 0.29 & 0.39 & 0.33 & 0.44 \\
\hline $\begin{array}{l}\text { Cost of gross } \\
\text { output, ha/€ } \\
\text { Pi }\end{array}$ & 714 & 959 & 878 & 1087 & 883 & 1122 & 736 & 994 & 345 & 463 \\
\hline $\begin{array}{l}\text { Differential } \\
\text { income, } € / \text { ha } \\
\text { DIa }\end{array}$ & 61 & 305 & 59 & 267 & 46 & 285 & 71 & 329 & 28 & 146 \\
\hline
\end{tabular}

Source: own study.

To calculate the score of a partial economic evaluation of lands on a definite working area (Table 4) according to payback of expenditures and differential income, it is necessary to calculate the value of the score using Formulas 3-4, and their evaluation score using Formula 5 and 6.

Table 4

Calculation of the score of a partial economic evaluation of lands according to payback of expenditures and differential income in a work area, 2017

\begin{tabular}{|c|c|c|c|c|c|c|c|c|c|c|c|}
\hline & & \multicolumn{10}{|c|}{ Agricultural crops } \\
\hline & & \multicolumn{2}{|c|}{ Winter wheat } & \multicolumn{2}{|c|}{ Sugar beets } & \multicolumn{2}{|c|}{ Grain maize } & \multicolumn{2}{|c|}{ Barley } & \multicolumn{2}{|c|}{ Winter rye } \\
\hline & & $33 \mathrm{~g}$ & $40 \mathrm{~g}$ & $33 \mathrm{~g}$ & $40 \mathrm{~g}$ & $33 \mathrm{~g}$ & $40 \mathrm{~g}$ & $33 \mathrm{~g}$ & $40 \mathrm{~g}$ & $33 \mathrm{~g}$ & $40 \mathrm{~g}$ \\
\hline Score of bonit & $t$ of a crop B & 13 & 23 & 3 & 4 & 10 & 17 & 11 & 20 & 26 & 45 \\
\hline \multirow{2}{*}{$\begin{array}{l}\text { Price of the } \\
\text { score }\end{array}$} & $\begin{array}{l}\text { payback of } \\
\text { expenditures, } \\
\text { PSpe }\end{array}$ & 0.03 & 0.02 & 0.52 & 0.39 & 0.04 & 0.02 & 0.03 & 0.02 & 0.01 & 0.01 \\
\hline & $\begin{array}{l}\text { differential } \\
\text { income, } \\
\text { PSdi }\end{array}$ & 15 & 8 & 54 & 41 & 19 & 11 & 19 & 10 & 4 & 2 \\
\hline \multirow{2}{*}{$\begin{array}{l}\text { Payback of } \\
\text { expenditures }\end{array}$} & hwt/100 €, PEa & 0.30 & 0.40 & 1.39 & 1.72 & 0.30 & 0.39 & 0.29 & 0.39 & 0.33 & 0.44 \\
\hline & $\begin{array}{l}\text { score, } \\
\text { SPEa }\end{array}$ & 11 & 26 & 3 & 4 & 8 & 19 & 9 & 23 & 22 & 51 \\
\hline \multirow{2}{*}{$\begin{array}{l}\text { Differential } \\
\text { income }\end{array}$} & $\begin{array}{l}\text { €/ha, } \\
\text { DIa }\end{array}$ & 61 & 305 & 59 & 267 & 46 & 285 & 71 & 329 & 28 & 146 \\
\hline & $\begin{array}{l}\text { score, } \\
\text { SDIa }\end{array}$ & 4 & 37 & 1 & 7 & 2 & 26 & 4 & 31 & 8 & 72 \\
\hline
\end{tabular}

Source: own study.

Differential income is a material basis for differential rent I (according to natural fertility) and II (according to economic fertility). It reveals the total value of the economic efficiency of land employment with consideration of its quality and level of intensity of arable farming at the enterprise. Thus, the calculated indicators of differential income are used by the authors of the article for comparison of the conditions of growing agricultural crops in the working areas of the enterprise. This is done on the basis of additional income from arable farming on better or medium lands as compared to the worse ones, due to more efficient labor productivity.

The saving of expenditures in the form of differential income is used as a criterion of optimization in plan calculations concerning the use of lands of different levels of their use intensity. 
Optimization of land-use management requires the application of indicators of differential income on better (40 g) and worse soils (33 g), using the matrix game in order to determine the optimal proportion of agricultural crops grown to provide maximum gross income.

The matrix game is a mathematical tool to model an agreement of the sides' interests. The mathematical model, which is called a game, answers the question concerning the necessary changes of the game conditions in order to achieve an efficient result of the new optimal strategy (SHYIAN, 2009). The strategy of a player is considered an optimal one if it supplies a maximum possible benefit or minimum possible loss after its multiple repetition. The strategy secures the most efficient result under any actions of the opponent and the value of the result is not reduced even under the worst conditions (VASYLIEVA 2015).

The largest differential income (a secured benefit) of the first player $\mathrm{A}_{1}$ at the worse soils is measured as:

$$
\mathrm{A}_{1}=\max _{\mathrm{i}=1} \min _{\mathrm{j}=1} \mathrm{x}_{\mathrm{ij}}
$$

The least differential income (a secured loss) of the second player $\mathrm{A}_{2}$ at the better soils of the enterprise is calculated as:

$$
\mathrm{A}_{2}=\min _{\mathrm{j}=1} \max _{\mathrm{i}=1} \mathrm{x}_{\mathrm{ij}}
$$

where: $\mathrm{Xij}$ - is the optimal strategy for the growing of the ij agricultural crop.

The authors of the article set out to find an optimal combination of agricultural crops in the structure of a cropping area on better or worse soils; thus one that will result in a maximum differential income under the mixed strategy of the game (Table 5).

Table 5

An optimal strategy for growing agricultural crops on better and worse soils under the mixed strategy

\begin{tabular}{|c|c|c|c|c|c|}
\hline \multirow{3}{*}{\multicolumn{2}{|c|}{$\begin{array}{c}\text { Optimal strategy for growing of } \\
\text { agricultural crops }\end{array}$}} & \multicolumn{2}{|c|}{ Differential income. $€ /$ ha } & \multirow{3}{*}{$\operatorname{minj}$} & \multirow{3}{*}{$\begin{array}{l}\text { Structure of the } \\
\text { cropping area. } \mathrm{Pi} j\end{array}$} \\
\hline & & \multirow{2}{*}{$\begin{array}{c}\text { worse soils } \\
33 \mathrm{~g} \\
\text { 1st player } \\
\mathrm{A}_{1}\end{array}$} & \multirow{2}{*}{$\begin{array}{c}\text { better soils } \\
40 \mathrm{~g}\end{array}$} & & \\
\hline & & & & & \\
\hline Winter wheat & $X_{1}$ & 61 & 305 & 61 & 0.25 \\
\hline Sugar beets & $\mathrm{X}_{2}$ & 59 & 267 & 59 & 0.25 \\
\hline Grain maize & $\mathrm{X}_{3}$ & 46 & 285 & 46 & 0.25 \\
\hline Barley & $\mathrm{X}_{4}$ & 71 & 329 & 71 & 0.25 \\
\hline Winter rye & $X_{5}$ & 28 & 146 & 28 & 0 \\
\hline $\max _{i}$ & & 71 & 329 & \multirow{2}{*}{$\begin{array}{l}\text { Objective } \\
\text { function } \\
\mathrm{V}\end{array}$} & \multirow{2}{*}{1} \\
\hline $\max _{\mathrm{i}} \min _{\mathrm{j}}$ & & 59 & 297 & & \\
\hline
\end{tabular}
of the game, 2017

Source: own study.

To reach the aim, the authors of the article optimize the objective function V in MS Excel by means of "Search for solution" customization:

$$
\mathrm{V}=\mathrm{X}_{1}+\mathrm{X}_{2}+\mathrm{X}_{3}+\mathrm{X}_{4}+\mathrm{X}_{5} \rightarrow \max
$$

Additional unknown variables Pij and restrictions are introduced to get the following figure:

$$
\left\{\begin{array}{c}
\max _{\mathrm{i}} \geq 0 \\
\mathrm{Pij} \geq 0 \\
\mathrm{~V}=1
\end{array}\right.
$$

The obtained results demonstrate that, according to the indicators of differential income at the enterprise, it is reasonable to introduce a four-course crop rotation with the average size of a field being 9.45 ha: I - winter wheat; II - sugar beets; III - grain maize; IV - barley.

According to the optimal structure of crop rotation for growing agricultural crops on better and worse soils, materials of the partial economic evaluation of lands, which are obtained under the mixed structure of the game, are used by the authors of the article for calculating the economic efficiency of 
growing them by Formulas 7-10. This is supplied by the indicators of general economic evaluation of lands at the enterprise (Table 6).

Table 6

Calculation of the indicators of general economic evaluation of lands at the enterprise, 2017

\begin{tabular}{|c|c|c|c|c|c|c|c|c|c|c|c|c|}
\hline \multirow{3}{*}{ 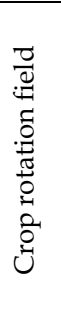 } & \multirow{3}{*}{$\begin{array}{l}\text { Agricultural } \\
\text { crops }\end{array}$} & \multirow{2}{*}{\multicolumn{2}{|c|}{$\begin{array}{l}\text { Agro-productive } \\
\text { group of soils }\end{array}$}} & \multirow{3}{*}{ 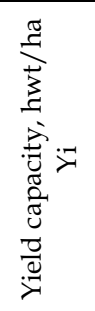 } & \multirow{3}{*}{ 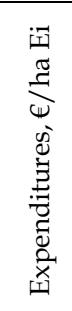 } & \multirow{3}{*}{ 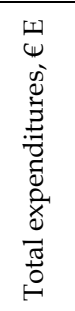 } & \multirow{3}{*}{ 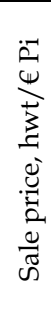 } & \multirow{3}{*}{ 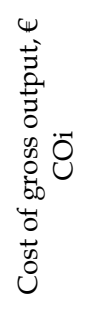 } & \multicolumn{4}{|c|}{$\begin{array}{c}\text { Indicators of economic evaluation } \\
\text { of lands }\end{array}$} \\
\hline & & & & & & & & & \multicolumn{2}{|c|}{$\begin{array}{c}\text { payback of } \\
\text { expenditures } \\
\text { PEi }\end{array}$} & \multicolumn{2}{|c|}{$\begin{array}{l}\text { differential } \\
\text { income DIi }\end{array}$} \\
\hline & & Code & $\begin{array}{l}\text { Area, ha } \\
\quad \mathrm{Ai}\end{array}$ & & & & & & $\begin{array}{c}\text { hwt } / 100 \\
€\end{array}$ & score & $€$ & score \\
\hline I & $\begin{array}{l}\text { Winter } \\
\text { wheat }\end{array}$ & $40 \mathrm{~g}$ & 9.45 & 58.71 & 9.3 & 549 & 16 & 9059 & 16.5 & 26 & 8318 & 37 \\
\hline II & Sugar beets & $40 \mathrm{~g}$ & 9.50 & 318.64 & 2.1 & 671 & 3 & 10322 & 15.4 & 4 & 9416 & 7 \\
\hline \multirow{2}{*}{ III } & \multirow{2}{*}{$\begin{array}{l}\text { Grain } \\
\text { maize }\end{array}$} & $40 \mathrm{~g}$ & 2.14 & 73.12 & \multirow{2}{*}{9.3} & 678 & \multirow{2}{*}{15} & 2401 & 3.5 & 19 & 1486 & 26 \\
\hline & & $33 \mathrm{~g}$ & 7.27 & 57.57 & & 534 & & 6422 & 12.0 & 8 & 5702 & 2 \\
\hline \multirow[b]{2}{*}{ IV } & \multirow{2}{*}{ Barley } & $40 \mathrm{~g}$ & 0.85 & 58.86 & \multirow[b]{2}{*}{9.5} & 560 & \multirow[b]{2}{*}{17} & 845 & 1.5 & 23 & 89 & 31 \\
\hline & & $33 \mathrm{~g}$ & 8.59 & 43.56 & & 414 & & 6318 & 15.3 & 9 & 5759 & 4 \\
\hline \multicolumn{2}{|c|}{ Total } & & 37.8 & & & 3405 & & 35367 & 64.2 & & 1160 & \\
\hline \multicolumn{9}{|c|}{ Weighted average score of economic evaluation of lands at the enterprise, Swa } & 13 & & 14 & \\
\hline
\end{tabular}

Source: own study.

At the enterprise, the weighted average score constitutes 13 - by payback of expenditures, and 14 by differential income. The obtained figures are insufficient. This is caused by a low level of humus in the soil. However, the obtained indices of a partial economic evaluation of land according to the yield capacity of agricultural crops, payback of expenditures and differential income in the absolute and relative values on better and worse soils of the enterprise (Table 6) should be applied for planning the cropping area of these crops, their yield capacity, the comparison of soil fertility and measurement of economic results of agricultural production, and the development of a complex of agro-technical measures on a working area of a crop rotation field in order to establish ecologically safe land use.

\section{Discussion and conclusions}

The methodical approach to the economic valuation of land can be used for any type of land use. The application of data of a partial economic evaluation of lands to supply sustainable development of land-use management on the example of a farming enterprise in Ukraine will support taking advantage of its productive and social potential, securing the development of rural territories and an increase in agricultural product output with a high added value for the country population. This will supply the Ukrainian market with quality products, facilitate the creation of new job positions in rural territories, and support the development of business entities and the national economy.

Differential income is a quantity characteristic of the relative fertility of lands. Indicators of the differential income are the basis for balancing the economic conditions of farming, organization and planning of agricultural production at the enterprise. The largest figure of the differential income is typical for better lands $(40 \mathrm{~g})$ under the growing of barley, i.e. $329 € /$ ha (score of 31) and winter wheat $-305 € /$ ha (score of 37), with the lowest figure being typical for worse soils (33 g) under the growing of winter rye - $146 € /$ ha (score of 8 ). On such soil, payback of expenditures constitutes $0.33 \mathrm{hwt} / 100 €$. Their values are taken into consideration for the optimization of land-use management by means of the metrical game. According to the indices of the differentiated approach, the obtained result of the mixed strategy of the game confirms that it is reasonable to introduce a four-field rotation at a farming enterprise with an average field size of 9.45 ha for growing such major agricultural crops as: I - winter wheat; II - sugar beet; III - grain maize; IV - barley, which can be recommended for the production specialization of business entities in the natural-agricultural province of the Western Forest-steppe of Ukraine.

\section{References}

Cherkasy regional state project-technological center of protection of soil fertility and products quality "Oblderzhrodiuchist", 2017, Soil observations of the farming enterprise "GREEN GARDEN", Cherkasy: 
ChRSPTC "Oblderzhrodiuchist", p. 30 (Ukraine).

CORKINDALE J., 1998, Towards the economic evaluation of British land use planning, conference: Workshop on Evaluation in Theory and Practice in Spatial Planning Location. - London: evaluation in planning: facing the challenge of complexity: book series: geojournal library, Vol. 47, pp. 343-354.

E-exchange of Ukraine "Grain Trade", Sale price for agricultural crops, 2017, [online], Available at: https://graintrade.com.ua/ (Ukraine).

IVASENKO A., 2008, Foreign experience of evaluation of agricultural land value, Vestnik UGTU-UPI, vol. 4, pp. 80-85 (Russia), p.84.

JAMES DeATON B., 2018, Agricultural economics: Key commitments and institutional alertness, 2018, [online], Available at: https://onlinelibrary.wiley.com/doi/epdf/10.1111/cjag.12192

KALOGIROU S., 2002, Expert systems and GIS: an application of land suitability evaluation, journal Computers, Environment and Urban Systems, Vol. 26, Issues 2-3, pp. 89-112, DOI: https://doi.org/10.1016/S0198-9715(01)00031-X.

KOVALYSHYN O., KRYSHENYK N., HAVRYSHKIV N., 2014, Analysis of methodological approaches to evaluation of land quality in Ukraine, Econtechmod. An International Quarterly Journal, Vol. 3, No. 4, p. 97-101.

KOVALYSHYN O., RYZHOK Z., 2017, Analysis of faithfulness of economic evaluation of lands under the current conditions of farming, messenger of Lviv National Agrarian University: economics of AIC - Lviv: LNAU, vol. 24(2), pp. 118-126 (Ukraine).

Law of Ukraine № 2768-III Land Code of Ukraine, 2001, [online], Available at: http://zakon3.rada.gov.ua/laws/show/2768-14 (Ukraine).

MAHAZYNSHCHYKOV T., 1991, Land cadaster, Lviv: Svit, p. 452 (Ukraine).

Main department of statistics in Lviv region, Report on the principal economic indicators of performance of agricultural enterprises in Lviv region in 2017, 2017 [online], Available at: http://www.lv.ukrstat.gov.ua/ (Ukraine).

Ministry of Agriculture of the USSR, All-union methodology of land evaluation (temporary), Moscow: Ministry of Agriculture of the USSR, 1976, $70 \mathrm{p}$.

PANNell D., GLENN N., 2000, A framework for the economic evaluation and selection of sustainability indicators in agriculture, Ecological Economics, Vol. 33, pp. 135-149, DOI: https://doi.org/10.1016/S0921-8009(99)00134-2.

ROSSITER D., 1995, Economic land evaluation: why and how, Soil Use and Management: International Journal for the British Society of Soil Science - Great Britain, vol. 11, pp. 132-140, DOI: 10.1088 / $1755-1315$ / 86/1/012013.

SHYIAN A., 2009, Game theory: fundamentals and application in the economics and management, Vinnytsia: VNTU, p. 164, (Ukraine).

SMAHA I., 2016, Methodological aspects of determining differential rent income on arable lands, a collection of scientific and technical works "Scientific herald of NLTU of Ukraine" - Lviv: NLTU, Vol. 26(6), pp. 152-156, DOI: https:// doi.org/10.15421/40260623.

SMith C., MCDONALD G., 1998, Assessing the sustainability of agriculture at the planning stage, Journal of Environmental Management, Vol. 52, pp. 15-37, DOI: https://doi.org/10.1006/jema.1997.0162.

StROKOV A., YAKUBOVICH E., KRASILNIKOV P., 2017, Economic and Ecological Evaluation of Land Use Change: Evidence from Karelia, Ekonomika Regiona-Economy Of Region, Vol. 13, Issue 2, pp. 422433, DOI: 10.17059 / 2017-2-8.

STUPEN M., MYKULA O., RADOMSKI S., 2012, Evaluation of land: a textbook / by the society. ed. M.G. Stupen - Lviv, Ltd. League-Press, p. 326, (Ukraine).

Temple L., Barret D., Blundo Canto G., Dabat M.H., DevauX-Spatarakis A., Faure G., et al , 2018, Assessing impacts of agricultural research for development: A systemic model focusing on outcomes, Research Evaluation, Vol. 27 (2): pp. 157-170, DOI: https://doi.org/10.1093/reseval/rvy005.

TROCHLYUK T., 2014, Ecological and economic conflict: agricultural use or cultivation of second generation biomass, messenger of T. Shevchenko National University of Kyiv "Economics" - Kyiv: KNUT, Vol. 7, pp. 85-92, DOI: 10.2527/af.2013-0011. 27.

TRUBINA M., 2014, Foreign experience of evaluation of agricultural land parcels: taxation aspect, Financial law, vol. 3, pp. 55-58 (Ukraine).

Ustaoglu E., Perpiña Castillo C., Jacobs-Crisioni C., Lavalle C., 2016, Economic evaluation of agricultural land to assess land use changes, Land Use Policy, England, vol. 56, pp. 125-146, DOI: 10.1016 / j.landusepol.2016.04.020. 
VASYLIEVA N., 2015, Economic and mathematic modeling in agriculture, Dnipropetrovsk: Bila K.O., p. 155 (Ukraine).

YUSHKOVA V., 2014, Economic evaluation of potential land resources in agriculture, Voronezh, p. 181 (Russia).

ZAMULA I., 2008, Land evaluation of agricultural lands, Problems of the theory and methodology of accounting, control and analysis - Zhytomyr: ZhDTU, Vol. 1(10), pp. 97-107, DOI: https://doi.org/10.26642/pbo-2008-1(10)-97-107.

ZUBETS M., SYTNYK V., BEZUHLYI M., 2008, Methodic recommendations concerning an optimal correlation of agricultural crops in crop rotations of different soil-climatic zones of Ukraine, Kyiv: Institute of Arable Farming of NAASU, p. 44 (Ukraine). 